\title{
Influence of Various Curing Methods on Compressive Strength Development of Portland Pozzolan Cement Concrete
}

\author{
I Made Alit Karyawan Salain \\ Civil Engineering Department, Udayana University, Bali, Indonesia \\ imaksalain@unud.ac.id
}

\begin{abstract}
Experimental study on influence of various curing methods on the compressive strength development of Portland pozzolan cement concrete has been realized. Natural sand was used as fine aggregate and crushed stone as coarse aggregate. The mix proportion of concrete was 1.0 PPC: 2.0 sand: 3.0 crushed stone, by weight, and a water/cement ratio was 0.5 . The test specimens were in the form of a cylindrical, sizing of $150 \mathrm{~mm}$ in diameter and $300 \mathrm{~mm}$ in height. After casting, the specimens were kept first in molds at room temperature for 1 day, then cured by realizing different methods of curing until used for the compressive strength test. Test of compressive strength was done at $3,7,28$ and 90 days. Four curing methods were realized: air curing (ACM), wet burlap curing (WBM), water ponding curing (WPM), and curing compound (CCM). The results show that various curing methods implemented on PPC concrete influence strongly the development of its compressive strength. The development of compressive strength of PPC concrete cured by ACM tends to stabilize after 7 days of hydration while that cured by WBM, CCM and WPM tend to continuous as a function of hydration time. The compressive strength of PPC concrete cured by WBM and CCM at 90 days of hydration can reach about $87 \%$ and $96 \%$ respectively of that cured by WPM which means that CCM could keep the saturated condition in concrete more effectively rather than WBM.
\end{abstract}

Keyword - Compressive Strength, Curing, Portland Pozzolan Cement

\section{INTRODUCTION}

The strength of concrete is influenced by various factors including characteristics and proportions of materials, curing conditions and testing parameters [1-3]. In concrete technology, curing, realized soon after the placement of a concrete mixture, is provided to push cement hydration developing strength. It consist of control of time, temperature and humidity. On a mixture of concrete, by setting the other factors are constant, the longer the moist curing period is given to concrete the higher the strength is developed, in condition that the hydration process of anhydrous cement particles is still going on.

On the on hand, it is well known that the strength development of concrete made by using Portland pozzolan cement (PPC), at a given mixture and normal temperature, is generally slower in the early age than that using ordinary Portland cement (OPC) [4]. The presence of pozzolan affects the reactivity of PPC and so the rates of strength development of concrete using this type of cement. Numerous study concerning effect of curing procedure on properties of pozzolan concrete cement have been realized before. Results of a study on properties of silica fume concrete show that steam curing enhances the strength of silica fume concrete while air curing present adverse effects compared to moist curing [5]. A study concerning effect of pozzolanic materials and curing methods on the elastic modulus of High Performance Concrete (HPC), made from mixes using various percentages of fly ash, silica fume and, granulated blast furnace slag, gives that dry curing and curing compound reduce the modulus of elasticity of HPC compared to wet curing with burlap [6]. A study on effect of different curing methods on the properties of microsilica concrete indicates that water curing as well as wrapped curing provided much better results than dry-air curing [7].

Generally, moist curing is provided by one or a combination of following methods: water spraying or water ponding as well as covering the surface of concrete with wet burlap. These methods are more suitable to be implemented for horizontal concrete members like beam and slab on concrete buildings. More complex and/or vertical concrete members such as bridge piers, cast in place, will surely present a certain difficulty for preventing the water loss from concrete if these methods used. In this case, it is likely more favorable to apply curing compound, serving as an impermeable membrane soon after casting, to maintain the cement hydration process as well as the development of concrete strength. However, it needs a study to evaluate the performance of those various curing methods on strength development of concrete, especially which made by using PPC as hydraulic binder.

In this experimental study, the influence of various curing methods on compressive strength development of concrete made by using PPC has been investigated. The curing methods studied include: air curing, covering concrete with wet burlap, water ponding curing, and spraying concrete with curing compound. The compressive 
strength test realized at 3, 7, 28 and 90 days using cylindrical specimens sizing $150 \mathrm{~mm}$ in diameter and $300 \mathrm{~mm}$ in height. The objective of this study was to measure the effectiveness of various curing methods on the compressive strength development of PPC concrete.

\section{Materials ANd EXPerimental Method}

As hydraulic binder, it was used PPC produced from one of cement manufactures in Indonesia. Natural sand and crushed stone originated from local area in Bali were used as fine aggregate and as coarse aggregate respectively. For mixing the concrete mixture, it was used water tap. Some physical properties of the hydraulic binder as well as those aggregates are given in Table 1. As curing compound, it was used paraffin based white pigmented that complied with ASTM C 309-89 Type II Class A [8].

TABLE I. PHYSICAL PROPERTIES OF HYDRAULIC BINDER AND AGGREGATES

\begin{tabular}{|l|c|c|c|}
\hline \multicolumn{1}{|c|}{ Physical Properties } & PPC & Fine Aggregate & Coarse Aggregate \\
\hline Unit weight $\left(\mathrm{g} / \mathrm{cm}^{3}\right)$ & 1.19 & 1.58 & 1.52 \\
\hline Specific gravity SSD & - & 2.54 & 2.32 \\
\hline Absorption (\%) & - & 3.63 & 2.74 \\
\hline Fineness Modulus & - & 2.28 & 7.30 \\
\hline Abrasion (\%) & - & - & 40.97 \\
\hline
\end{tabular}

For realizing the investigation, concrete made by a mixture proportion of 1.0 PPC: 2.0 sand: 3.0 crushed stone, by weight, was prepared. The water/cement ratio was 0.5 . The test specimens were in the form of a cylindrical, sizing of $150 \mathrm{~mm}$ in diameter and $300 \mathrm{~mm}$ in height. All the specimens were prepared in accordance with Indonesian Standard SNI 2493:2011[9]. After casting, the specimens were kept first in molds at room temperature for 1 day, then they were cured by realizing different methods of curing until used for the compressive strength test. Test of compressive strength, realized according to SNI 03-1974-1990 [10], was done at 3, 7, 28 and 90 days, each using 3 cylindrical specimens. Four methods of curing were implemented i.e. air curing (ACM), curing with wet burlap (WBM), water ponding curing (WPM), and curing compound (CCM). The ACM specimens were placed all days and nights on the exterior floor of the laboratory while the WBM specimens were placed on the interior floor of the laboratory covered with burlap wetted every 3 days. The WPM was realized by placing the specimens in a plastic box flooding with water whereas the CCM was applied in liquid form by spraying on all surface of the specimens. The four methods of curing realized in this experiment are presented in Figure 1.

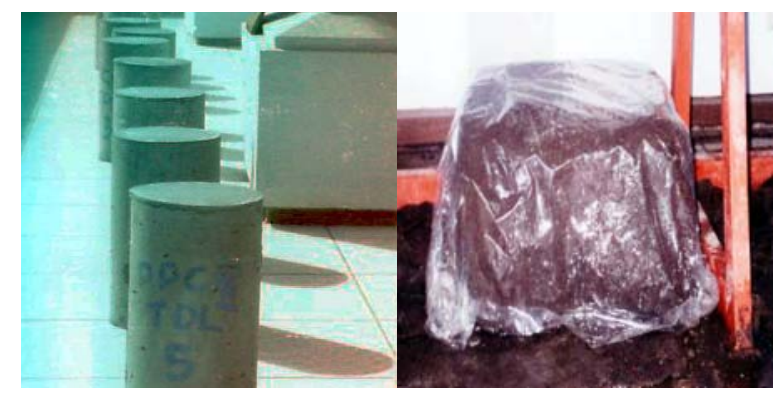

a. Air Curing

b. Wet Burlap

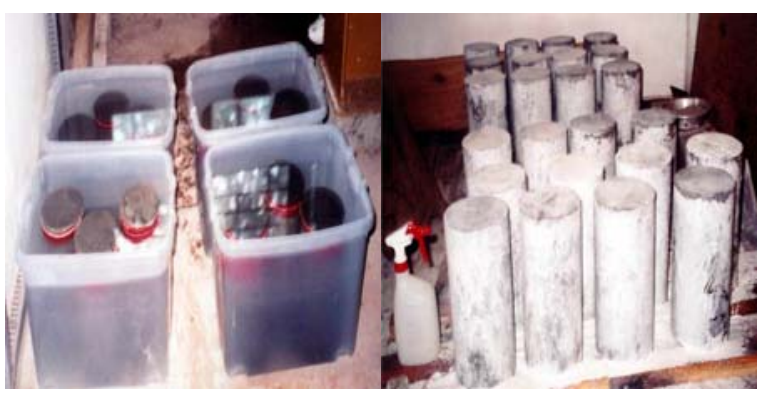
c. Water Ponding
d. Curing Compound

Fig. 1. Cylindrical specimens with four different methods of curing 


\section{III.RESULTS AND DISCUSSION}

\section{A. Results}

The results of the compressive strength from test on cylindrical specimens at the age of 3, 7, 28 and 90 days for various methods of curing are shown in Table 2. The trend lines of the compressive strength development is presented in Figure 2. This figure illustrates the influence of moist curing on the development of the compressive strength of concrete made by using PPC with the hydration time.

TABLE II. Compressive Strength Test Results

\begin{tabular}{|l|c|c|c|c|}
\hline \multirow{2}{*}{\multicolumn{1}{|c|}{ Method of Curing }} & \multicolumn{4}{c|}{ Compressive Strength (MPa) } \\
\cline { 2 - 5 } & 3 days & 7 days & 28 days & 90 days \\
\hline Air Curing (ACM) & 12.03 & 15.28 & 18.11 & 17.97 \\
\hline Wet Burlap (WBM) & 20.94 & 26.31 & 30.18 & 31.50 \\
\hline Water Ponding (WPM) & 23.25 & 26.27 & 29.99 & 36.22 \\
\hline Curing Compound (CCM) & 18.11 & 26.03 & 30.42 & 34.80 \\
\hline
\end{tabular}

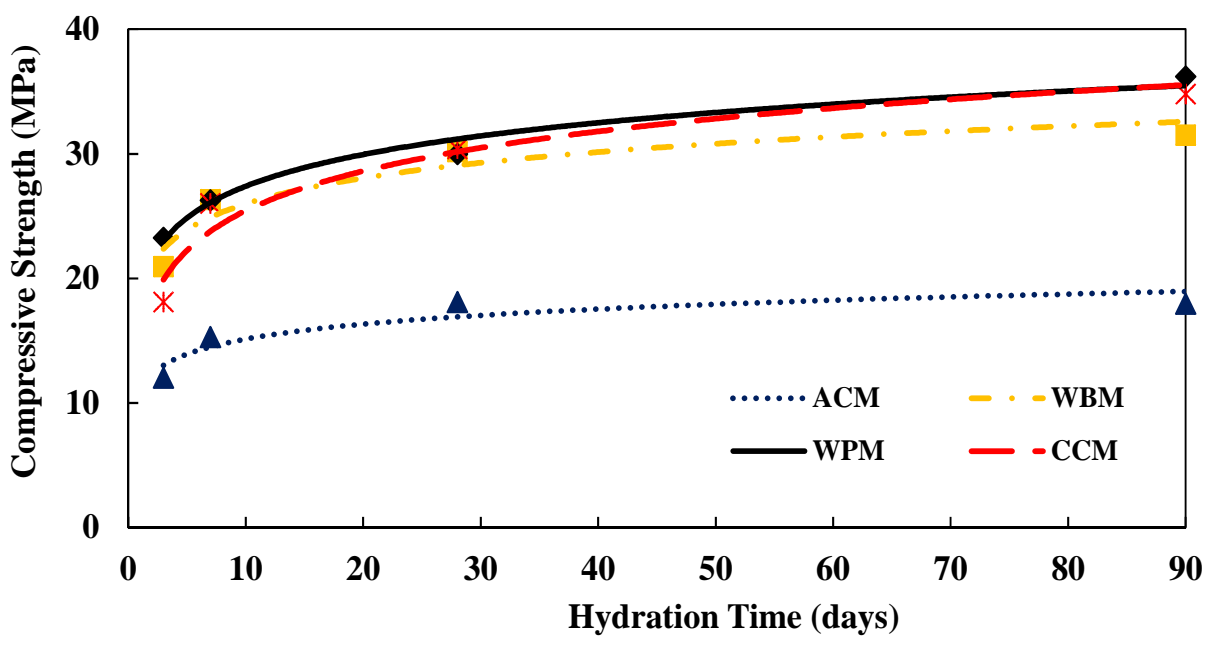

Fig. 2. Compressive strength as a function of curing method and hydration age

From those table and figure, it is observed that the compressive strength in concrete cured by ACM develops only for the first 7 days of hydration and then it develops slightly or even tends to stabilize with hydration time. At every age of hydration time, this concrete produces the weakest compressive strength compared to concrete cured by other three curing methods. Even after 90 days of hydration, concrete cured by ACM can only develop maximum $50 \%$ of the compressive strength cured by WPM.

On the other hand, it is clearly noted that the compressive strength develops strongly during the hydration time in concrete cured by WBM, WPM and CCM. The compressive strength of concrete cured by these three curing methods tends to develop in relatively a similar way until 28 days of hydration. Nevertheless, after long period of hydration (90 days), the compressive strength concrete cured by WBM and CCM can only reach respectively $87 \%$ and $96 \%$ of that cured by WPM. It is also noted that from 7 days to 28 days, the compressive strength gain of concrete cured by WBM, WPM and CCM reaches 15\%, 14\% and 17\% respectively and from 28 days to 90 days, it reaches $4 \%, 21 \%$ and $14 \%$ respectively.

\section{B. Discussion}

Compressive strength test result shows that the development of compressive strength of PPC concrete cured by ACM tends to stabilize after 7 days of hydration. Even after 90 days of hydration, the compressive strength developed in this concrete is only about 50\% of that cured by WPM. This phenomenon, which is also indicated in OPC concrete $[1,2]$, is clearly related to the fact that the ACM cannot prevent the water loss from PPC concrete, during the early stage of hydration, due to temperature, humidity relative and velocity of wind. This condition makes that the compressive strength is hardly not increase with the hydration time.

On the other hand, although the compressive strength development of PPC concrete cured by WBM and CCM shows relatively the same tendency until 28 days of hydration compared to that cured by WPM, however their compressive strength at 90 days of hydration can only reach respectively about $87 \%$ and $96 \%$ of that cured by WPM. The higher strength produces by PPC concrete cured by WPM caused by the fact that the concrete is always in contact with water which prevents the moisture movement from and into the concrete and assures certainly the strength development. A relatively lower strength in long term observed in concrete cured by 
WBM and CCM compared to that cured by WPM are closely influenced by the curing condition implemented. In fact, WBM and CCM prevent, to certain extent, the water loss in concrete to assure the hydration process of PPC. However, it seems that CCM could keep the saturated condition in concrete more effectively rather than WBM. This phenomenon is relied that concrete cured by WBM is not continuously in contact with water and wet curing is applied intermittently so the moist curing is relatively discontinuous, while concrete cured by CCM is sealed by an impermeable membrane which prevents effectively evaporation of water from concrete.

\section{IV.CONCLUSION}

The following conclusions are drawn based on the experimental study realized.

- Various curing methods implemented on PPC concrete influence strongly the development of its compressive strength.

- The development of compressive strength of PPC concrete cured by ACM tends to stabilize after 7 days of hydration while that cured by WBM, CCM and WPM tend to continuous as a function of hydration time.

- The compressive strength of PPC concrete cured by WBM and CCM at 90 days of hydration can reach about $87 \%$ and $96 \%$ respectively of that cured by WPM which means that CCM could keep the saturated condition in concrete more effectively rather than WBM.

\section{ACKNOWLEDGMENT}

The author thank Udayana University for providing all the facilities and all colleagues who have supported to realize this experimental study.

\section{REFERENCES}

[1] P. K. Mehta, Concrete Structure Properties, and Materials, Englewood Cliffs, New Jersey, 1986.

[2] M. Neville and J. J. Brooks, Concrete Technology, Longman, Singapore, 1998.

[3] F. M. Lea, The Chemistry of Cement and Concrete, Edward Arnold Ltd., London, 1970.

[4] I M. A. K. Salain, "Effect of Accelerator on Compressive Strength Development of Class F Fly Ash Concrete”, International Journal of Engineering and Technology, vol. 9 (5), pp. 3954-3957, Oct-Nov. 2017.

[5] H. A. Toutanji and Z. Bayasi, "Effect of Curing Procedures on Properties of Silica Fume Concrete", Cement and Concrete Research, vol. 29 (4), pp. 497-501, April 1999.

[6] H. H. Nassif, H. Najm and N. Suksawang, "Effect of Pozzolanic Materials and Curing Methods on the Elastic Modulus of HPC", Cement and Concrete Composites, vol. 27 (6), pp. 661-670, July 2005.

[7] M. Safiuddin, S. N. Raman and M. F. M. Zain, "Effect of Different Curing Methods on the Properties of Microsilica Concrete”, Australian Journal of Basic Applied Science, vol. 1 (2), pp. 87-95, 2007.

[8] Standard Specification for Liquid Membrane-Forming Compounds for Curing Concrete, ASTM C 309-89, USA.

[9] Tata Cara Pembuatan dan Perawatan Benda Uji Beton di Laboratorium (In Indonesian), SNI 2493, Badan Standardisasi Nasional, Jakarta, Indonesia, 2011

[10] Test method for compressive strength of concrete, SNI 03-1974, Badan Standarisasi Nasional, Jakarta, Indonesia, 1990.

\section{AUTHOR PROFILE}

I Made Alit Karyawan Salain is a lecturer at Civil Engineering Department of Udayana University in Bali, Indonesia. He is a Civil Engineer from Bandung Institute of Technology in Bandung, Indonesia, DEA and DR in Civil Engineering from INSA de Lyon in France. His research focused on concrete technology and valorization of industrial wastes in the field of Civil Engineering. 